\title{
Self-Efficacy and its Relationship with Future Orientation and Coping Styles for a Sample of Technical Secondary Students
}

Sara Ragab Elsayed*

\section{Abstract}

The study examined the relationship between self-efficacy and future orientation, and the relationship between self-efficacy and coping styles. It was conducted on a sample of 150 technical school students. Mean age of the sample 17.42 years with S.D \pm 1.14 . The researcher used self-efficacy scale, future orientation scale, and coping styles scale (prepared by the researcher). Results of the study indicated that there is a positive relationship between self-efficacy and future orientation. Also found a positive relationship between self-efficacy and Active coping, also a positive relationship between self-efficacy and positive reappraisal, and there is a negative relationship between self-efficacy and venting of emotions, also a negative relationship between selfefficacy and avoidance.

Key words: Self-efficacy- Future orientation- Coping styles.

$* * * *$

\section{Introduction:}

Self-efficacy refers to people beliefs in their capabilities to perform specific action required to attain desired outcomes (Luszczynska, Scholz, \& Schwarzer, 2005: 439), students with confidence in their own abilities are more inclined to engage in difficult tasks and show higher effort, whereas students that exhibit low levels of self-efficacy will try to evade such tasks by setting only easily attainable goals (Ziegler \& Opdenakker, 2018: 72).

Thinking about the future is a key characteristic of the individuals. Individuals do wonder about what will happen to them in the future, they have future goals and wishes, and they face the challenge of trying

* Assistant lecturer at department of psychology, faculty of Arts, Mansoura University. E-mail: sararagab59@yahoo.com 
to realize them. Future orientation is the phrase most commonly used to express a person's expectations about the future and the actions they carry out related to the future (Di Maggio, Ginevra, Nota, \& Sores, 2016: 115).

Coping and its strategies are becoming increasingly important in the psychology field. The actions we perform to cope with stress and the strategies that we adopt to handle it can determine the learning process, a subject's development and also his/her quality of life. From this perspective, coping is considered a part of the psychosocial competence, which includes the behavioral, cognitive and emotional strategies employed by a subject to cope with life's demands (Salavera, Usan, Perez, Chato, \& Vera, 2017: 1310-1311).

\section{Self-efficacy and future orientation:}

Self-efficacy refers to one's belief in one's ability to cope with adversity and to achieve goals. It is the perceived ability to adapt one's behavior to environmental demands. Self-efficacy influences people's thoughts and behaviors. People with high levels of self-efficacy tend to anticipate successful outcomes to scenarios; therefore, they are more likely to take on difficult tasks, which they perceive as challenges. Consequently, they set high goals, persevere longer and invest more effort in achieving objectives. They also tend to choose activities they consider to be under their control (Trouillet, Gana, Lourel, \& Fort, 2009: 358).

Future orientation refers to person's thoughts, plans, aspirations, and his feelings about the future (Stoddard, Zimmerman, \& Bauermeister, 2011: 239). Self-efficacy related to individual's adolescent's internal beliefs about his or her level of competence and ability to perform well in the future. According to self-efficacy theory, behaviors, motivation, and aspirations are influenced by whether an individual believes in his or her ability to attain a specific outcome. The more efficacious students feel, the more they persist in their current academics, and this has implications for their future opportunities (Kerpelman, Eryigit, \& Stephens, 2008: 999).

There are few studies examined the relationship between selfefficacy and future orientation such as study of (Kerpelman et al., 2008) which conducted on American adolescents, and study of (Azizli, Atkinson, Baughmah, \& Giammarco, 2015) which conducted on college 
students in Canada. These studies showed that there is a positive relationship between self-efficacy and future orientation.

\section{Self-efficacy and coping styles}

Coping with stressful situations is an essential characteristic of the human experience. According to Lazarus, coping is based upon an interaction between the individual's appraisal and response to a stimulus. An individual first appraises a stimulus to determine if a threat is present. If there is a perception of harm, the individual then engages in a coping response. Lazarus and Folkman (1987) state that a coping response can be either problem-focused or emotion-focused. Problem-focused coping can be defined as strategies to influence the situation, whereas emotion-focused coping is described as efforts to minimize emotional distress (Straud, McNaughton-Cassill, \& Fuhrmam, 2015: 60).

Self-efficacy is considered to influence the way we face external situations, it can be viewed as a personal resource factor that may facilitate active and positive coping strategies where efforts are invested to solve problems with respect to one's goals (Trouillet et al., 2009: 358).

Studies that examined the relationship between self-efficacy and coping were on college students such as (Dwyer \& Cummings, 2001; Shikai, Hiramura, \& Shono, 2007; Khan, 2013; Kandemir, Ilhan, Özpolat, \& Palanc, 2014), other studies were on adolescents such as (yang, Yang, Liu, Tian, Zhu, \& Miao, 2010), while no studies examined it on technical secondary students.

The results of studies that examined the relationship between selfefficacy and coping styles (avoidance, emotion-focused coping, problem-focused coping) were inconsistent. The results of some studies showed that there is a negative relationship between self-efficacy and avoidance such as (Rai, 1995); while the results of (Shikai et al., 2007) showed that there is no relationship between self-efficacy and avoidance. The results of some studies such as (Shikai et al., 2007) showed that there is a negative relationship between self-efficacy and emotion-focused coping, some studies such as (Bodys-Cupak, Majda, Zalewska- Puchala, \& Kaminska, 2016) showed that there is a positive relationship between self-efficacy and problem-focused coping, while the study of (Dwyer, \& Cummings, 2001) which showed that there is no 
relationship between self-efficacy and coping styles (problem-focused coping, emotion-focused coping, avoidance).

The results of studies that examined the relationship between selfefficacy and (seeking social support, positive reappraisal) were consistent. It showed that there is a positive relationship between selfefficacy and seeking social support such as (Bodys-Cupak et al., 2016; Yang et al., 2010), and there is a positive relationship between selfefficacy and positive reappraisal such as (Bodys-Cupak et al., 2016; Khan, 2013).

\section{Hypotheses:}

After reviewing the theoretical framework and previous studies, the study hypotheses can be formulated as follows:

1. There is a positive relationship between self-efficacy and future orientation among a sample of Technical secondary students.

2. There is a positive relationship between self-efficacy and (active coping, seeking for social support, positive reappraisal), and there is a negative relationship between self-efficacy and (wishful thinking, venting of emotions, avoidance) among a sample of Technical secondary students.

\section{Method:}

\section{Participants:}

The participants were 150 students between 16 and 19 years old $(\mathrm{M}=17.42$, S.D \pm 1.14$), 75$ boys and 75 girls. The students are studying in developed commercial technical secondary school (five years system). The school is in Talkha, Governorate of Dakahlia. Students are of $2^{\text {nd }}, 3^{\text {rd }}$ and $4^{\text {th }}$ year of study.

\section{Scales}

1. Self-efficacy scale (prepared by the researcher)

Although there are a lot of scales that are used to measure selfefficacy, there are few scales conducted on high school students such as (Mahmud, 2016), and there are no scales to measure self-efficacy among technical secondary students. 
After doing the first image of the scale, the researcher applied the scale on a pilot study consisted of (150) students have the same characteristics of the main sample.

\section{Validity of self-efficacy}

The researcher used factorial validity through Principle Component factor analysis, with orthogonal rotation. The factor analysis of the items yielded four high loaded factors labeled effort, perseverance, selfconfidence and tendency to difficult tasks. Table (1) Presents 37 items loadings on the four factors.

Table (1)

Loadings of items on the four factors after rotation

\begin{tabular}{|c|c|c|c|c|c|c|c|}
\hline $\mathbf{N}$ & Factor 1 & $\mathbf{N}$ & Factor 2 & $\mathbf{N}$ & Factor 3 & $\mathbf{N}$ & Factor 4 \\
\hline 1 & 0.72 & 10 & 0.63 & 20 & 0.64 & 29 & 0.58 \\
\hline 2 & 0.62 & 11 & 0.58 & 21 & 0.62 & 30 & 0.52 \\
\hline 3 & 0.61 & 12 & 0.53 & 22 & 0.58 & 31 & 0.45 \\
\hline 4 & 0.59 & 13 & 0.49 & 23 & 0.54 & 32 & 0.44 \\
\hline 5 & 0.58 & 14 & 0.48 & 24 & 0.46 & 33 & 0.44 \\
\hline 6 & 0.50 & 15 & 0.47 & 25 & 0.46 & 34 & 0.37 \\
\hline 7 & 0.47 & 16 & 0.43 & 26 & 0.39 & 35 & 0.35 \\
\hline 8 & 0.46 & 17 & 0.43 & 27 & 0.39 & 36 & 0.33 \\
\hline 9 & 0.42 & 18 & 0.42 & 28 & 0.35 & 37 & 0.32 \\
\hline & & 19 & 0.38 & & & & \\
\hline Eigen value & 2.82 & \multicolumn{2}{|r|}{2.40} & \multicolumn{2}{|r|}{2.27} & \multicolumn{2}{|r|}{1.67} \\
\hline Percentages of variance & $7.05 \%$ & & $6 \%$ & \multicolumn{2}{|c|}{$5.68 \%$} & \multicolumn{2}{|r|}{$4.18 \%$} \\
\hline
\end{tabular}

The researcher also used criteria validity and finding the correlation between self-efficacy scale (By the researcher) and self-efficacy scale (By Sherer, Mercandante, Prentice-dunn, Jacobs, Rogers, 1982. Translated and modified by Mahmud, 2016) ( $\mathrm{r}=0.80, \mathrm{p}<.01)$ denoting the scale validity.

\section{Reliability of self-efficacy Scale}

Split-half reliability with Guttman was 0.86 among the pilot sample; Alpha reliability was 0.83 denoting high internal consistency and temporal reliability. 


\section{Internal Consistency of self-efficacy Scale:}

The researcher also used internal consistency by finding the correlation between item and dimension, then the correlation between dimension and total score of self-efficacy scale. The coefficients between items and first dimension (Effort) range between 0.18 and 0.67 $(\mathrm{P}<0.05-0.01)$. The coefficients between items and second dimension (perseverance) range between 0.43 and $0.66(\mathrm{P}<0.01)$. The coefficients between items and third dimension (self-confidence) range between 0.34 and 0.60 ( $\mathrm{P}<0.01)$. The coefficients between items and fourth dimension (tendency to difficult tasks) range between 0.39 and $0.60(\mathrm{P}<$ $0.01)$.

The coefficients between the four dimensions and the total score were: $(\mathrm{r}=0.70,0.86,0.69$ and $0.80 \mathrm{P}<0.01)$.

The scale in its final image contains 37 short statements answered on a 3-point format, anchored by 1 (Disagree) and 3 (Agree) in positive direction and anchored by 3 (Disagree) and 1 (Agree) in negative direction. The total score can range from 37 to 111.

2. Future orientation (prepared by the researcher)

Most scales of future orientation were conducted on foreign countries, few scales were conducted on Arab countries such as (Hegazi, 2008) on college students, so the researcher prepared new scale to fit Egyptian environment and Technical secondary students.

\section{Validity of future orientation:}

The factor analysis of the items yielded three high loaded factors labeledpositive expectations, planning, and consideration of future consequences. Table (2) Presents 32 items loadings on the three factors. 
Table (2)

Loadings of items on the three factors after rotation

\begin{tabular}{|c|c|c|c|c|c|}
\hline $\mathbf{N}$ & Factor 1 & $\mathbf{N}$ & Factor 2 & $\mathbf{N}$ & Factor 3 \\
\hline $\mathbf{1}$ & 0.74 & 12 & 0.67 & 25 & 0.75 \\
\hline $\mathbf{2}$ & 0.71 & 13 & 0.66 & 26 & 0.60 \\
\hline $\mathbf{3}$ & 0.67 & 14 & 0.65 & 27 & 0.50 \\
\hline $\mathbf{4}$ & 0.62 & 15 & 0.56 & 28 & 0.49 \\
\hline $\mathbf{5}$ & 0.59 & 16 & 0.52 & 29 & 0.47 \\
\hline $\mathbf{6}$ & 0.57 & 17 & 0.51 & 30 & 0.39 \\
\hline $\mathbf{7}$ & 0.55 & 18 & 0.50 & 31 & 0.38 \\
\hline $\mathbf{8}$ & 0.54 & 19 & 0.49 & 32 & 0.35 \\
\hline $\mathbf{9}$ & 0.46 & 20 & 0.49 & & \\
\hline $\mathbf{1 0}$ & 0.44 & 21 & 0.48 & & \\
\hline $\mathbf{1 1}$ & 0.40 & 22 & 0.40 & & \\
\hline & & 23 & 0.34 & & \\
\hline & & 24 & 0.33 & & \\
\hline & $\mathbf{3 . 7 1}$ & \multicolumn{3}{|c|}{$\mathbf{3 . 5 0}$} & $\mathbf{2 . 0 5}$ \\
\hline Percentages of variance & $\mathbf{1 0 . 3 1 \%}$ & $\mathbf{9 . 2 7 \%}$ & $\mathbf{5 . 6 9 \%}$ \\
\hline
\end{tabular}

The researcher also used criteria validity and finding the correlation between future orientation scale (By the researcher) and future orientation scale (By Steinberg, Graham, O'Brien, Woolard, Cauffman, Banich, 2009. Translated to Arabic by Kasim, Shahin, \& Saeid, 2014) $(\mathrm{r}=0.80, \mathrm{p}<.01)$ denoting the scale validity.

\section{Reliability of future orientation Scale:}

Split-half reliability with Guttman was 0.82 among the pilot sample; Alpha reliability was 0.85 denoting high internal consistency and temporal reliability.

\section{Internal Consistency of future orientation Scale:}

The researcher also used internal consistency by finding the correlation between item and dimension, then the correlation between dimension and total score of future orientation scale. The coefficients between items and first dimension (positive expectations) range between 0.39 and $0.65(\mathrm{P}<0.01)$. The coefficients between items and second dimension (planning) range between 0.30 and $0.67(\mathrm{P}<0.01)$. The coefficients between items and third dimension (Tendency to difficult tasks) range between 0.38 and $0.64(\mathrm{P}<0.01)$. 
The coefficients between the three dimensions and the total score were: $(r=0.82,0.86$ and $0.76 \mathrm{P}<0.01)$.

The scale in its final image contains 32 short statements answered on a 3-point format, anchored by 1 (Disagree) and 3 (Agree) in positive direction and anchored by 3 (Disagree) and 1 (Agree) in negative direction. The total score can range from 32 to 96.

\section{Coping scale: (prepared by the researcher)}

There are many psychological scales that measure coping styles, but the scales that measure coping styles among high school students are few, and it is noticeable that most of these scales were prepared a long time ago such as (Vitaliano, Russo, Carr, Maiuro, \& Becker, 1985; Carver, Scheier, \& Weintraub, 1989; AbdElmoati, 1994) which were conducted on college students.

The factor analysis of the items yielded six high loaded factors labeled, wishful thinking, venting of emotions, avoidance, active coping, seeking for social support, and positive reappraisal. Table (3) Presents 58 items loadings on the six factors.

\section{Table (3)}

\section{Loadings of items on the six factors after rotation}

\begin{tabular}{|c|c|c|c|c|c|c|c|c|c|c|c|}
\hline $\mathbf{N}$ & $\begin{array}{c}\text { Factor } \\
1 \\
\end{array}$ & $\mathbf{N}$ & $\begin{array}{c}\text { Factor } \\
2 \\
\end{array}$ & $\mathbf{N}$ & $\begin{array}{c}\text { Factor } \\
\mathbf{3} \\
\end{array}$ & $\mathbf{N}$ & $\begin{array}{c}\text { Factor } \\
4 \\
\end{array}$ & $\mathbf{N}$ & $\begin{array}{c}\text { Factor } \\
5 \\
\end{array}$ & $\mathbf{N}$ & $\begin{array}{c}\text { Factor } \\
6 \\
\end{array}$ \\
\hline 1 & 0.78 & 11 & 0.68 & 21 & 0.77 & 31 & 0.72 & 40 & 0.62 & 49 & 0.48 \\
\hline 2 & 0.69 & 12 & 0.63 & 22 & 0.67 & 32 & 0.63 & 41 & 0.61 & 50 & 0.47 \\
\hline 3 & 0.68 & 13 & 0.61 & 23 & 0.62 & 33 & 0.62 & 42 & 0.50 & 51 & 0.45 \\
\hline 4 & 0.66 & 14 & 0.60 & 24 & 0.58 & 34 & 0.60 & 43 & 0.45 & 52 & 0.45 \\
\hline 5 & 0.57 & 15 & 0.56 & 25 & 0.55 & 35 & 0.60 & 44 & 0.44 & 53 & 0.44 \\
\hline 6 & 0.49 & 16 & 0.54 & 26 & 0.51 & 36 & 0.47 & 45 & 0.44 & 54 & 0.41 \\
\hline 7 & 0.47 & 17 & 0.54 & 27 & 0.46 & 37 & 0.44 & 46 & 0.42 & 55 & 0.39 \\
\hline 8 & 0.45 & 18 & 0.54 & 28 & 0.40 & 38 & 0.38 & 47 & 0.37 & 56 & 0.37 \\
\hline 9 & 0.42 & 19 & 0.47 & 29 & 0.37 & 39 & 0.37 & 48 & 0.37 & 57 & 0.34 \\
\hline 10 & 0.41 & 20 & 0.43 & 30 & 0.33 & & & & & 58 & 0.31 \\
\hline Eigen value & 3.32 & \multicolumn{2}{|c|}{3.19} & \multicolumn{2}{|c|}{2.94} & \multicolumn{2}{|c|}{2.72} & \multicolumn{2}{|c|}{2.05} & \multicolumn{2}{|c|}{1.72} \\
\hline $\begin{array}{l}\text { Percentage } \\
\text { s of } \\
\text { variance }\end{array}$ & $5.53 \%$ & \multicolumn{2}{|c|}{$5.32 \%$} & \multicolumn{2}{|c|}{$4.90 \%$} & \multicolumn{2}{|c|}{$4.53 \%$} & \multicolumn{2}{|c|}{$3.42 \%$} & \multicolumn{2}{|c|}{$2.87 \%$} \\
\hline
\end{tabular}

The researcher also used criteria validity and finding the correlation between total degree of positive dimensions of coping scale (By the researcher) and total degree positive dimensions of coping scale (By AbdElmoati, 1994) $(\mathrm{r}=0.83, \mathrm{p}<.01)$ denoting the scale validity. The 
researcher also used criteria validity and finding the correlation between total degree of negative dimensions of coping scale (By the researcher) and total degree of negative dimensions of coping scale (By AbdElmoati, 1994) $(r=0.78, \mathrm{p}<.01)$ denoting the scale validity.

\section{Reliability of coping Scale:}

Table (4) presents reliability coefficients of coping scale using splithalf and alpha.

\section{Table (4)}

Reliability coefficients of coping scale

\begin{tabular}{|l|c|c|}
\hline \multicolumn{1}{|c|}{ Coping scale's dimension } & Guttman & Alpha \\
\hline Wishful thinking & 0.84 & 0.82 \\
\hline Venting of emotions & 0.85 & 0.82 \\
\hline Avoidance & 0.76 & 0.73 \\
\hline Active coping & 0.70 & 0.76 \\
\hline Seeking for social support & 0.74 & 0.75 \\
\hline Positive reappraisal & 0.65 & 0.66 \\
\hline
\end{tabular}

Table (4) presented high internal consistency and temporal reliability.

\section{Internal Consistency of coping Scale}

The researcher also used internal consistency by finding the correlation between item and dimension, then the correlation between dimension and total score of coping scale. The coefficients between items and first dimension (Wishful thinking) range between 0.52 and $0.74(\mathrm{P}<0.01)$. The coefficients between items and second dimension (venting of emotions) range between 0.50 and $0.71(\mathrm{P}<0.01)$. The coefficients between items and third dimension (Avoidance) range between 0.35 and $0.72(\mathrm{P}<0.01)$. The coefficients between items and fourth dimension (Active coping) range between 0.41 and $0.65(\mathrm{P}<$ 0.01). The coefficients between items and fifth dimension (seeking for social support) range between 0.44 and $0.70(\mathrm{P}<0.01)$. The coefficients between items and sixth dimension (positive reappraisal) range between 0.42 and $0.59(\mathrm{P}<0.01)$.

The scale in its final image contains 58 short statements answered on a 3-point format, anchored by 1 (Disagree) and 3 (Agree). 


\section{Results of the study:}

Table (5) shows the correlation coefficient between the scores of the subjects on self-efficacy scale and on future orientation scale.

\section{Table (5)}

Pearson correlation coefficient between self-efficacy and future orientation

\begin{tabular}{|l|l|l|l|c|c|}
\hline Self-efficacy & Effort & Perseverance & $\begin{array}{c}\text { self- } \\
\text { confidence }\end{array}$ & $\begin{array}{c}\text { tendency } \\
\text { to } \\
\text { difficult } \\
\text { tasks }\end{array}$ & $\begin{array}{c}\text { Self- } \\
\text { efficacy } \\
\text { 'total } \\
\text { score' }\end{array}$ \\
\hline positive expectations & $0.38^{* *}$ & $0.37 * *$ & 0.12 & $0.21^{* *}$ & $0.37 * *$ \\
\hline Planning of future & $0.49 * *$ & $0.31^{* *}$ & 0.14 & $0.28^{* *}$ & $0.40^{* *}$ \\
\hline $\begin{array}{l}\text { Consideration of } \\
\text { consequences. }\end{array}$ & $0.41^{* *}$ & $0.18^{*}$ & 0.08 & 0.14 & $0.27 * *$ \\
\hline $\begin{array}{l}\text { Future orientation 'total } \\
\text { score' }\end{array}$ & $0.52^{* *}$ & $0.35^{* *}$ & 0.13 & $0.27 * *$ & $0.43^{* *}$ \\
\hline
\end{tabular}

It is clear from Table (5) that there is a positive relationship between self-efficacy and future orientation for a sample of technical secondary students. There is a positive relationship between effort and (positive expectation, planning, consideration of future consequences, the total score of future orientation). There is a positive relationship between perseverance and (positive expectations, planning, consideration of future consequences, the total score of future orientation). There is no relationship between self-confidence and (positive expectation, planning, consideration of future consequences, the total score of future orientation). There is a positive relationship between tendency to difficult tasks and (positive expectation, planning, the total score of future orientation), and there is no relationship between tendency to difficult tasks and consideration of future consequences). There is a positive relationship between self-efficacy and (positive expectation, planning, consideration of future consequences).

Table (6) shows the correlation coefficient between the scores of the subjects on self-efficacy scale and on the six dimensions of coping scale. 


\section{Table (6)}

Pearson correlation coefficient between self-efficacy and coping styles

\begin{tabular}{|l|c|c|c|c|c|}
\hline Self-efficacy & Effort & Perseverance & $\begin{array}{c}\text { self- } \\
\text { confidence }\end{array}$ & $\begin{array}{c}\text { tendency to } \\
\text { difficult tasks }\end{array}$ & $\begin{array}{c}\text { Self-efficacy } \\
\text { 'total score' }\end{array}$ \\
\hline Woping styles & -0.11 & -0.13 & -0.06 & -.044 & $0.12-$ \\
\hline $\begin{array}{l}\text { Venting of } \\
\text { emotions }\end{array}$ & $-0.20^{*}$ & $-0.20^{*}$ & -0.02 & -0.07 & $0.17-^{*}$ \\
\hline Avoidance & -0.12 & $-0.17^{*}$ & -0.01 & -0.17 & $0.16^{*}$ \\
\hline Active coping & $0.30^{* *}$ & $0.19^{*}$ & 0.15 & $0.17^{*}$ & $0.26^{* *}$ \\
\hline $\begin{array}{l}\text { Seeking for social } \\
\text { support }\end{array}$ & 0.07 & 0.08 & 0.01 & 0.04 & 0.07 \\
\hline $\begin{array}{l}\text { Positive } \\
\text { reappraisal }\end{array}$ & $0.31^{* *}$ & 0.15 & 0.06 & $0.21^{* *}$ & $0.24^{* *}$ \\
\hline
\end{tabular}

It is clear from Table (6) that there is a positive relationship between self-efficacy and Active coping, also a positive relationship between self-efficacy and positive reappraisal. There is a negative relationship between self-efficacy and venting of emotions, also a negative relationship between self-efficacy and avoidance. There is no relationship between self-efficacy and wishful thinking. There is no relationship between self-efficacy and seeking for social support.

There is a negative relationship between venting of emotions and (effort, perseverance). There is a negative avoidance and perseverance. There is a positive relationship active coping and (effort, perseverance, tendency to difficult tasks). There is a positive relationship between positive reappraisal and (effort, tendency to difficult tasks).

\section{Discussion:}

The results of this study indicates that there is a positive relationship between self-efficacy and future orientation, this result consists with what Kerperlman and his colleagues (Kerperlman et al., 2008: 999) pointed out, that self-efficacy fits with future orientation and an individual's internal beliefs about his or her level of competence and ability to perform well in the future. According to self-efficacy theory, behaviors, motivation, and aspirations are influenced by whether an individual believes in his or her ability to attain a specific outcome. The more efficacious students feel, the more they persist in their current academics, and this has implications for their future opportunities 
Self-efficacy influences the extent to which individuals engage in future planning. Those who adopt a future-oriented approach are more likely to be prepared for future tasks and to exert more control while completing a task. These goal-oriented skills allow individuals to focus on new opportunities to achieve goals (Azizli et al., 2015: 58).

self-efficacy is correlated with future orientation, that the student who trusts in his or her abilities, will make effort, continue to work despite the difficulties and tend to difficult tasks, and will have positive expectations regarding to his educational, vocational and personal future, and will plan to achieve his/her future goals, and will think of future consequences of any decision or action.

Students who have positive expectations about their future and plans to achieve their goals will do their best in studying, will never give up but persist to achieve everything they want, and tend to perform difficult tasks that challenge their abilities.

There is a positive relationship between consideration of future consequences and effort that students who think about future consequences of his actions to achieve success in his life, will make effort to achieve his goals.

There is a weak relationship between consideration of future consequences and perseverance that students who think about before make decision may persist to achieve their goals.

The results of this study also indicates that there is a positive relationship between self-efficacy and active coping, also a positive relationship between self-efficacy and positive reappraisal. There is a negative relationship between self-efficacy and venting of emotions, also a negative relationship between self-efficacy and avoidance.

Coping models emphasize the role of both individual and social resources in influencing individuals' appraisal of stressful events and coping strategies. One individual resource is self-efficacy. People with high assurance in their capability will approach difficult tasks as challenges to be mastered, rather than as threats to be avoided. When stressors are controllable, such an efficacious outlook produces personal accomplishments, reduces stress, and lowers vulnerability to depression. Self-efficacy should be particularly relevant in enhancing internal, 
cognitive problem-solving strategies and in reducing withdrawal strategies (Cicognani, 2011: 561).

The student who believes in his/her efficacy on solving the problems, he/she will face and think about the alternatives to solve them, and try to see the problem from a positive perspective, he/she won't avoid his/her problems, and won't get upset and feel emotional distress, but he/she will focus all his/her thinking on the problem, so the researcher believes that students who have high self-efficacy will deal with the pressures better than those who have low self-efficacy.

Students who make effort and persist in his academic life will attain low scores on venting of emotions and avoidance. The students who have high scores on active coping and positive reappraisal will have high scores on effort and tendency of difficult tasks.

\section{References:}

AbdElmoati, H. M. (1994). Life events stress and its coping styles "A comparative civilizational study between the Egyptian and Indonesian society". Egyptian Journal of Psychological Studies, (8).

Azizli, N., Atkinson, B., Baughmah, H., \&Giammarco, E. (2015). Relationships between general self-efficacy, Planning for the future, and life satisfaction. Personality and Individual Differences, 82, 58-60.

Bodys-Cupak,I., Majda, A., Zalewska- Puchala,J.,\& Kaminska, A. (2016). The impact of a sense of self- efficacy on the level of stress and the ways of coping with difficult situations in polish nursing students. Nurse Education Today, 45, 102-107.

Carver, C. S., Scheier M. F., Weintraub, J.K. (1989). Assessing coping strategies: a theoretically based approach. J PersSocPsychol, 56 (2), 267-283.

Cicognani, E. (2011). Coping strategies with mirror stressors in adolescences relationships with social support, self-efficacy and psychological wellBeing, Journal of Applied Social Psychology. 41 (3), 559- 578.

Di Maggio, I., Ginevra, M. C., Nota, L., \& Sores, S. (2016). Development and validation of an instrument to assess future orientation and resilience in adolescence. Journal of adolescence, 51 (Aug), 114-122.

Dwyer, A., \& Cummings, A. (2001). Stress, self-efficacy, social support, and coping strategies in university students. Canadian Journal of Counseling, 35, 208-220. 
Hegazi, G. H. (2008). Psychological alienation and its relationship with achievement motivation and future orientation among the Palestinian university youth, journal of faculty of Arts, Tanta university, 3 (21). 9921083.

Kerpelman, J. L., Eryigit. S., \&Stephens. (2008). African American adolescents' future orientation: Associations with self-efficacy, Ethnic identity, and perceived parental support. J Youth Adolescence, 37, 9971008.

Kasim, N, F., Shahin, E, F., Saeid, M. O. Future orientation scale. Journal of Faculty of Education, Ain Shams University, 3 (38), 955-977.

Kandemir, M., Ilhan, T., Özpolat, A. R., Palanc, M. (2014). Analysis of academic self-efficacy, self-esteem and coping with stress skills predictive power on academic procrastination. Educational Research and Reviews, 9 (5), 146-152.

Khan, M. (2013). Academic self-efficacy, coping, Academic performance in college. Journal of undergraduate Research and Creative, 4, 1-11.

Luszczynska, A., Scholz, U., Schwarzer, R. (2005). The General self efficacy scale: Multicultural validation studies. The Journal of Psychology, 139 (5), 439-457.

Mahmud, N. A. (2016). The General self-efficacy scale. Cairo: Anglo Egyptian Bookshop.

Salavera, C., Usan, P., Perez, S., Chato, A., \&Vera, R. (2017). Differences in happiness and coping with stress in secondary education students. Procedia-Social and Behavioral Sciences, 237, 1310-1315.

Shikai, N., Hiramura, H., \&Shono, M. (2007). The Role of coping styles and self-efficacy in the development of dysphoric mood among nursing students. Journal of Psychology and Behavioral Assessment, 29 (4), 241-248.

Stoddard, S. A., Zimmerman, M. A.,\& Bauermeister, J. A. (2011) Thinking about the future as a way to succeed in the present: A long of future orientation and violent behaviors among African American youth. Am J Community Psychology, 48, 238-246.

Straud, C., McNaughton-Cassill, M., \& Fuhrman, R. (2015). The role of the five factor model of personality with proactive coping and preventative coping among college students. Personality and Individual Differences, 83, 60-64. 
Rai, S. H. (1995). The relationship between coping styles and gender, age, self-efficacy and desirability of control among college students. PhD, Indiana University.

Trouillet, R., Gana, K., Lourel, M., \& Fort, I. (2009). Predictive value of age for coping: The value of self-efficacy, social support satisfaction and perceived stress. Aging \& Mental Health, 13 (3), 357-366.

Vitaliano, P.P., Russo J, Carr, J. E., Maiuro, R.D., \&Becker J. (1985). The ways of coping checklist: Revision and psychometric properties. Multivariate Behav Res, 20 (1), 3-26.

Yang, J., Yang, Y., Liu, X., Tian, J., Zhu, X., \& Miao, D. (2010). Selfefficacy, social support, and coping strategies of adolescent earthquake survivors in China. Social Behavior and Personality: An international journal, 38, 1219-1228.

Ziegler, N., \&Opdenakker, M. (2018). The development of academic procrastination students: The link with metacognitive self- regulation, self-efficacy and effort regulation, Learning and individual Differences, $64,71-82$.

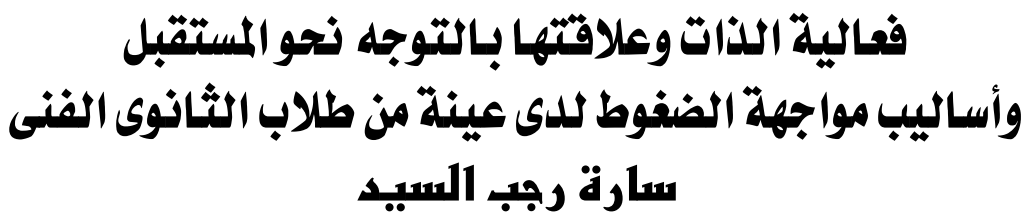

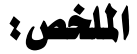

هدفت الدراسـة الحالية إلى التعرف على العلاقة بين فعالية الذات والتوجـه نحو المستقبل لدى عينة من طلاب الثانوي الفني، وكذلك التعرف على العلاقة بين فعالية الذات وأساليب مواجهة الضغوط. أُجريت الدراسـة على • 10 طالب وطالبة من طلاب الثانوى الفنى بواقع (Vo) طالبًا و(V0) طالبة، تتراوح أعمارهم ما

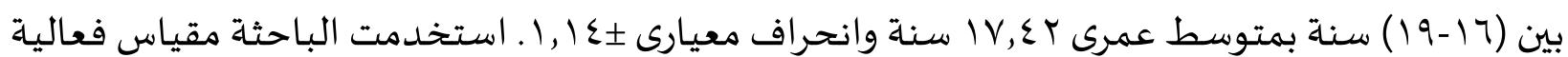
الذات (إعداد الباحثة)، ومقياس التوجه نحو المستقبل (إعداد الباحثة)، ومقياس أساليب مواجهة الضغوط (إعداد الباحثة)، وقد تأكدت الباحثة من الخصيائص السيكومترية للمقاييس بأكثر من طريقة. أوضحت نتائج الدراسـة أنها توجد علاقة موجبة بين فعالية الذات والتوجها نحو المستقبل، كما توجد علاقة موجبة بين فعالية الذات والمواجهة النشطة واعادة التقييم الإيـجابى، كما أوضحت النتائج أنها توجد علاقة سالبـة بين فعالية الذات والتنفيس عن الانفعالات والتجنب، وقد تم تفسير نتائج الدراسـة فى ضوء الإطار النظرى والدراسـات السابقة. الكلمات المفتاحية: فعالية الذات- التوجها نحو المستقبل- أسـاليب مواجهة الضغوط. 


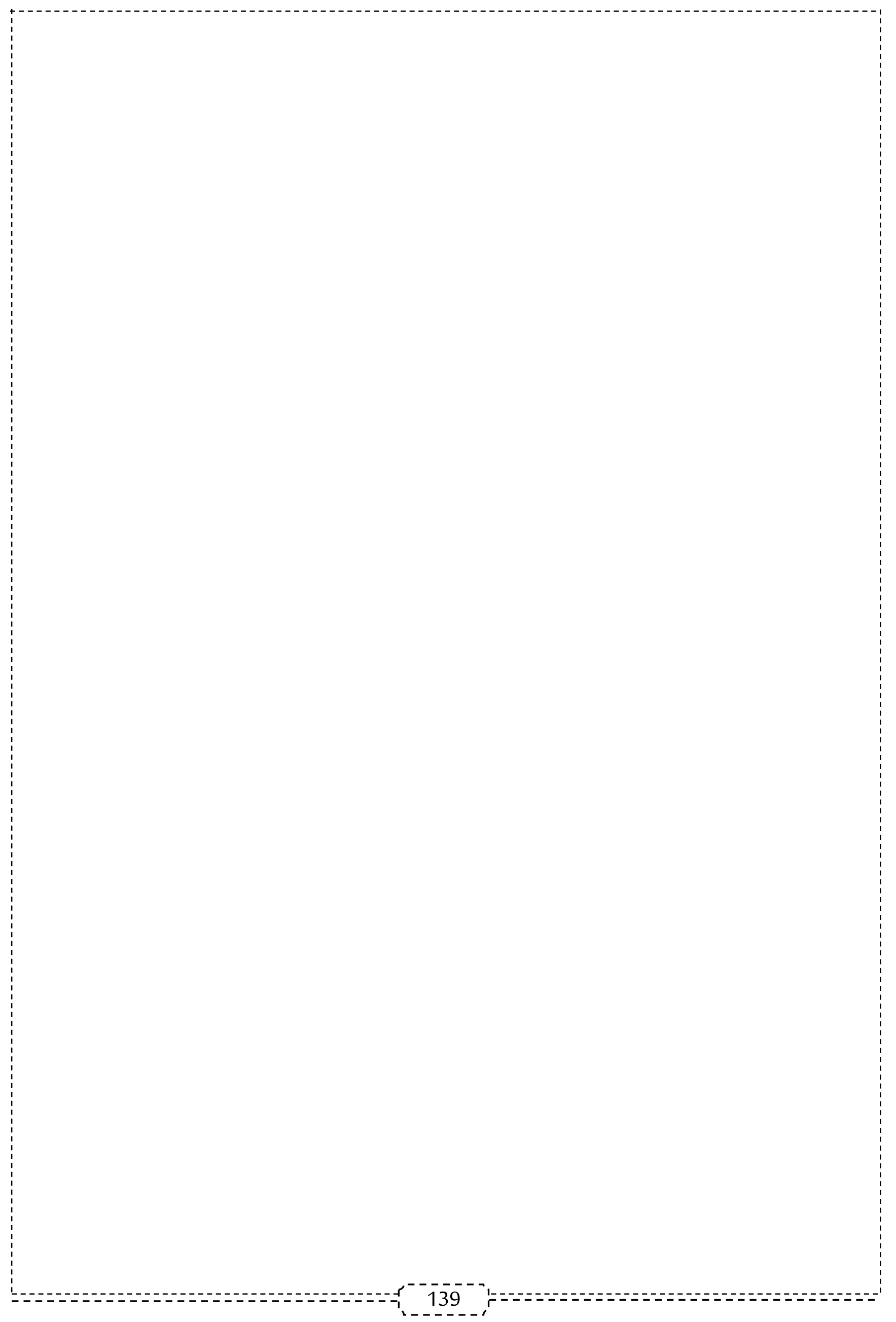

